\title{
Retraction of Applying Virtual Reality to Study the Effects of Environmental Education on College Students' Ethics and Environmental Literacy
}

Qiong Liu, Dafeng Gong, Min Chen *

Issue Date: 17 December 2018

Original Article: Applying Virtual Reality to Study the Effects of Environmental Education on College Students' Ethics and Environmental Literacy

EURASIA J. Math., Sci Tech. Ed (2018), 14(6), 2255-2263.

https:// doi.org/10.29333/ejmste/85937

This document states that the Article is retracted. All authors agree to the retraction of the Article.

\author{
http://www.ejmste.com
}

(C) 2019 by the authors; licensee Modestum Ltd., UK. This article is an open access article distributed under the terms and conditions of the Creative Commons Attribution License (http://creativecommons.org/licenses/by/4.0/). \360070981@qq.com 《289133894@qq.com \minchen@wzu.edu.cn (*Correspondence) 